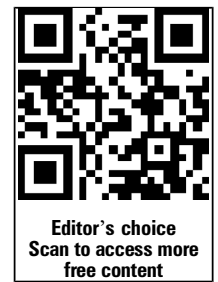

Department of Epidemiology and Health Statistics, School of Public Health, Central South University, Changsha, China

\section{Correspondence to}

Dr Guoqing Hu, Department of Epidemiology and Health Statistics, School of Public Health, Central South University. 110 Xiangya Road, Changsha 410078, China; huguoqing009@gmail.com.

Received 2 April 2013 Revised 11 July 2013 Accepted 29 July 2013 Published Online First 7 September 2013
To cite: He Q, Kang W, Tian $\mathrm{D}$, et al. Inj Prev 2014;20:148-154.

\title{
Analysis of the quantity and quality of published randomised controlled trials related to injury prevention from 2001 to 2010 in China
}

\author{
Qiong He, Wenjing Kang, Danping Tian, Yuanxiu Huang, Lin Gao, Xin Deng, Li Li, \\ Guoqing $\mathrm{Hu}$
}

ABSTRACT

Objective To report the quantity and quality of published randomised controlled trails (RCT) on injury prevention in China.

Design Bibliometric analysis.

Setting China, 2001-2010.

Data sources The published RCTs that were indexed by four domestic electronic databases and two international databases between 1 January 2001 and 31 December 2010.

Main outcome measures Numbers and proportions of published RCTs and those that did not report or specify the quality items recommended by Cochrane Handbook for Systematic Reviews of Intervention V.5.0.0.

Results Of 4834 publications of injury prevention, 25 RCTs with 55431 participants were identified. One study had no full text. Twenty-three RCTs were published in Chinese language. All 25 studies chose education as the intervention, including 19 studies using education as single intervention and 6 studies using education as a part of combined intervention. Eighteen of 19 studies that used injury incidence rate as the primary outcome measure; 10 studies reported $24-59 \%$ reductions in injury incidence rate in the intervention group, and 8 studies reported $24-76 \%$ rate difference between the intervention group and the control group after the implementation of intervention. Only 1 study reported no significant difference. The other 6 studies only reported improvements in knowledge, attitude and practice/ behaviour. None of 24 studies with full text included the information of 'allocation concealment', 'blinding' and 'free of early stopping bias'.

Conclusions The value of 25 published RCTs cannot be determined due to the lack of quality information. More high-quality RCTs need to be performed in the future.

\section{INTRODUCTION}

Injuries are a serious public health problem in China, resulting in about 700 000-750 000 deaths, 14 million hospitalisations, and 70 million emergency department visits. ${ }^{1}$ Despite the fact that injury prevention has received little support of the government, ${ }^{2} 3$ injury research has begun to attract more and more attention of researchers since the early 1990s. Consequently, the number of research publications on injury control has increased vastly in China since 2000. Unfortunately, a qualitative review by a leading domestic injury researcher indicated that most published papers on injury prevention in China were of low quality based on 475 papers between 2000 and $2005 .^{4}$

Injury research provides the base for policy development. Low-quality research may draw wrong conclusions and mislead the policy making of government. Among all types of original research, randomised controlled trails (RCT) are widely recognised as the best design type to establish the effectiveness of health intervention. ${ }^{5}$ To systematically review the published RCTs in China is important for the development of injury prevention at practical and research levels by summarising effective interventions of reported studies and identifying research priorities of future studies. However, the quality of published RCTs on injury prevention of the last decade and the rapid development period of injury research in China, has not been quantitatively examined so far.

In this present study, we aimed to examine the quantity and quality of published RCTs on injury prevention in China between 2001 and 2010.

\section{METHODS}

\section{Inclusion and exclusion criteria}

We confined the publications to RCTs that involved preventative interventions of fatal and non-fatal injuries in China, not including quasiexperiments. RCTs that focus on clinic treatment and rehabilitation of injured patients were excluded. We adopted the general definition of injuries given by $\mathrm{WHO}{ }^{6}$ 'A bodily lesion at the organic level, resulting from acute exposure to energy (mechanical, thermal, electrical, chemical or radiant) in amounts that exceed the threshold of physiological tolerance. In some cases (eg, drowning, strangulation, freezing), the injury results from an insufficiency of a vital element.' We covered merely the studies where the definition of injury outcome was consistent with WHO's definition. RCTs that were irrelevant to human beings were also excluded.

When more than one publication of an eligible RCT was detected, we chose the publication that reported primary outcomes and details of methods of the trial.

\section{Literature search method}

To maximally capture eligible studies, we conducted literature search using four domestic electronic databases (Chinese Biomedicine Literature Database, 1978 to present; China Science Literature Network Publish General Storeroom, 1979 to present; Chinese Science \& Technology Journal Database, 1989 to present; WanFang 
database, 1980 to present) and two international databases (PubMed, 1949 to present; Web of Knowledge, 1900 to present). PubMed has been available since 1996. Its over 22 million references include the MEDLINE database plus another eight types of citations. ${ }^{7}$ The Web of Knowledge that we used is an academic citation indexing and search service. It is combined with web linking and is provided by Thomson Reuters and covers the sciences, social sciences, arts and humanities of 17 electronic databases. ${ }^{8}$

The search strategies were first developed for the Chinese Biomedicine Literature Database and the PubMed based on keywords or Medical Subject Headings for injuries and China, restricting articles published in English and Chinese. Search terms for the concept of injuries were 'injuries', 'poisoning', 'accidents' and 'wounds and injuries'. These terms were searched separately. The valid date of literature search was confined to 1 January 2001 through 31 December 2010 since there were few injury research publications being conducted in China before 2001 . $^{9}$

\section{Study selection}

Two authors (QH and $\mathrm{WK}$ ) independently read the titles and abstracts of publications to decide whether to retrieve them in full. When an article appeared to be eligible based on the title but an abstract was unavailable, it was retrieved in full. Full texts of included articles were reviewed by the same researcher to determine whether they met the inclusion criteria. Any disagreement between researchers was resolved by discussion or referral to a third reviewer $(\mathrm{GH})$.

\section{Data extraction}

All the data were extracted by QH and WK using a standardised data-extraction form independently. The form included the information of the name of first author, year and language of publication, type of injury, age of study participants, sample size, interventions for intervention group and control group, duration of intervention, primary outcome measures, and intervention effects. Any discrepancy between two reviewers was dealt with discussion. GH adjudicated any discrepancy in opinion.

\section{Quality assessment}

Two reviewers (QH and $\mathrm{WK})$ independently assessed the methodological quality of included studies, applying the assessment tool recommended by Cochrane Handbook for Systematic Reviews of Intervention V.5.0.0. ${ }^{10}{ }^{11}$ The assessment tool includes seven items: sequence generation, allocation concealment, blinding, incomplete data outcomes, selective outcome reporting, baseline imbalance and early stopping. Each item was rated as low risk of bias (yes), high risk of bias (no), and unclear (absent or unclear), respectively. Any disagreement in the quality of studies between two reviewers was dealt with through discussion until consensus was reached.

\section{Analysis}

Frequency and percentage were used to reflect the quantity and quality of included RCTs. All the analyses were performed using the SPSS statistical software package V.18.0 and Microsoft Excel V.2010.

\section{RESULTS}

\section{Search results}

We initially retrieved a total of 27138 potentially related articles from domestic databases $(n=23$ 893) and international databases $(n=3245)$ using search strategies listed above. Totally 5469 duplicate publications and 10897 irrelevant publications were removed by reviewing the titles and abstracts (figure 1). Of 10772 injury-related publications, 4834 articles that focus on injury prevention were retained. Further, 98 experimental studies were identified and retrieved for full-text review. Finally, 25 RCTs were identified.

\section{Characteristics of studies}

Twenty-three of 25 published RCTs for injury prevention interventions were reported in Chinese (table 1). Nineteen studies centred on children and adolescents. Unintentional injury was
Figure 1 Selection of randomised controlled trials (RCT) for injury prevention interventions of China, 2001-2010

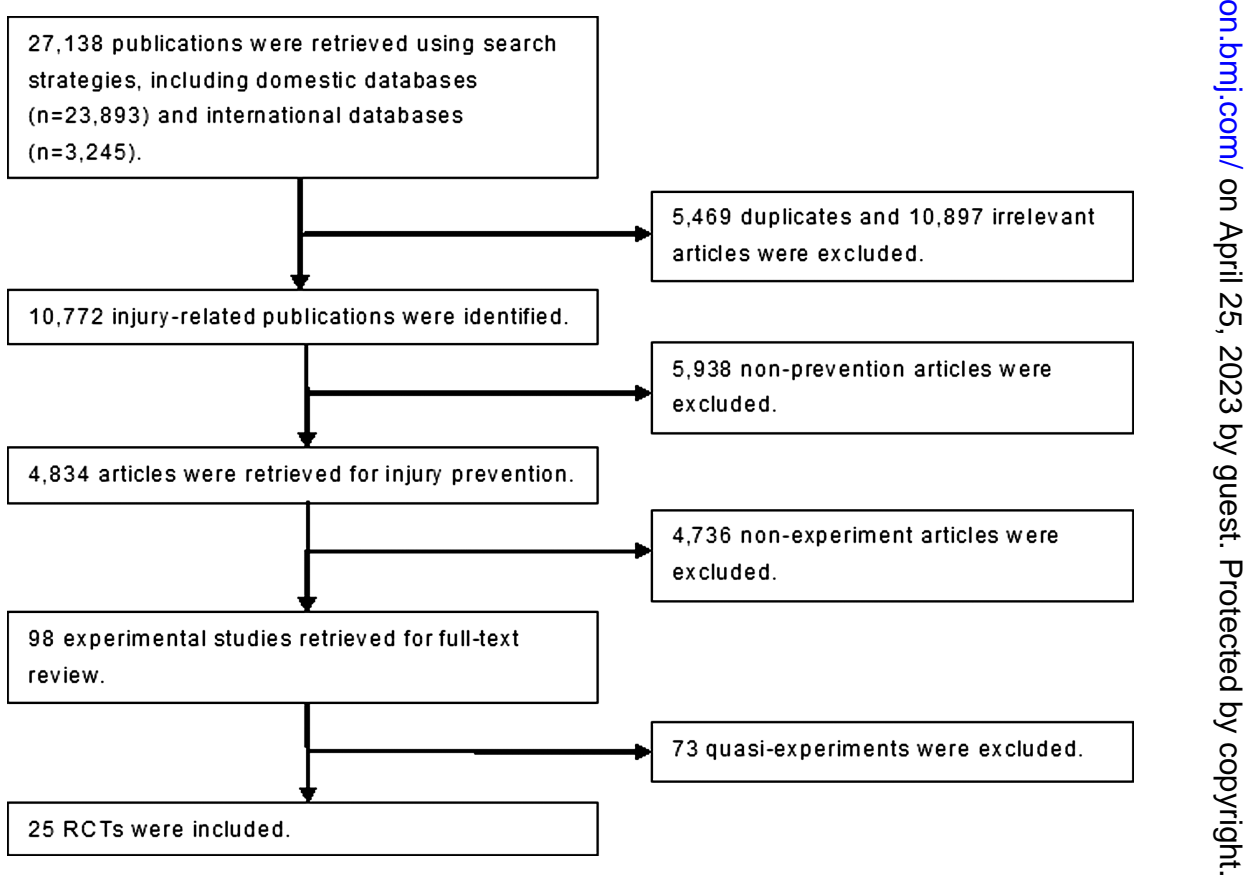




\begin{tabular}{|c|c|c|c|c|c|c|c|c|}
\hline \multirow[b]{2}{*}{ ID } & \multirow[b]{2}{*}{ Type of injury } & \multirow[b]{2}{*}{ Year } & \multirow[b]{2}{*}{ Sample size } & \multirow[b]{2}{*}{ Study subjects } & \multicolumn{2}{|l|}{ Prevention intervention } & \multirow[b]{2}{*}{ Outcome measures } & \multirow[b]{2}{*}{ Effects of intervention } \\
\hline & & & & & Intervention group & Control group & & \\
\hline Dong et $a l^{12 *}$ & All injuries & 2001 & $\begin{array}{l}\text { (1) } 2758 \dagger \\
\text { (2) } 2503 \ddagger\end{array}$ & Rural residents & $\begin{array}{l}\text { Injury education/environmental } \\
\text { check }\end{array}$ & None & (1) Incidence & $\begin{array}{l}\text { (1) Decreased by } 42 \% \text { ( } 463 \text { vs } 268 \text { per } 10000 \\
\text { persons)§ }\end{array}$ \\
\hline Yan et $a l^{13 *}$ & All injuries & 2001 & $\begin{array}{l}\text { (1) } 2409 \dagger \\
\text { (2) } 2786 \ddagger\end{array}$ & Rural residents & $\begin{array}{l}\text { Injury education/environmental } \\
\text { check }\end{array}$ & None & (1) Incidence & $\begin{array}{l}\text { (1) Decreased by } 37 \% \text { ( } 361 \text { vs } 228 \text { per } 10000 \\
\text { persons)§ }\end{array}$ \\
\hline Zhang et $a l^{14 *}$ & All injuries & 2001 & $\begin{array}{l}\text { (1) } 1733 \dagger \\
\text { (2) } 610 \neq\end{array}$ & Adolescents & Injury education & None & (1) Incidence & $\begin{array}{l}\text { (1) Decreased by } 50 \% \text { ( } 510 \text { vs } 253 \text { per } 1000 \\
\text { persons)§ }\end{array}$ \\
\hline $\mathrm{Guo}^{15 *}$ & All injuries & 2004 & $\begin{array}{l}\text { (1) } 2624 \dagger \\
\text { (2) } 2515 \ddagger\end{array}$ & Children & Injury education & $\begin{array}{l}\text { Non-injury } \\
\text { education }\end{array}$ & (1) Behaviour & (1) Improved§ \\
\hline Zhang $^{16 *}$ & $\begin{array}{l}\text { Unintentional } \\
\text { injury }\end{array}$ & 2004 & $\begin{array}{l}\text { (1) } 2550 \dagger \\
\text { (2) } 2429 \ddagger\end{array}$ & Children (mean: 8.7 years) & Injury education & $\begin{array}{l}\text { Non-injury } \\
\text { education }\end{array}$ & (1) Incidence & $\begin{array}{l}\text { (1) Decreased by } 28 \% \text { (387 vs } 279 \text { per } 1000 \\
\text { persons)ף }\end{array}$ \\
\hline Shen et $a l^{17 *}$ & $\begin{array}{l}\text { Unintentional } \\
\text { injury }\end{array}$ & 2004 & $\begin{array}{l}\text { (1) } 100 \dagger \\
\text { (2) } 100 \ddagger\end{array}$ & $\begin{array}{l}\text { Young adults (mean: } \\
33 \text { years) }\end{array}$ & Injury education & None & $\begin{array}{l}\text { (1) Incidence } \\
\text { (2) Safety awareness }\end{array}$ & $\begin{array}{l}\text { (1) Decreased by } 62 \% \text { ( } 39 \text { vs } 15 \text { per } 10000 \\
\text { persons)ף } \\
\text { (2) Improved } 7\end{array}$ \\
\hline $\begin{array}{l}\text { Wang and } \\
\text { Chen } \\
18 *\end{array}$ & $\begin{array}{l}\text { Unintentional } \\
\text { injury }\end{array}$ & 2005 & $\begin{array}{l}\text { (1) } 186 \dagger \\
\text { (2) } 194 \ddagger\end{array}$ & Adolescents & Injury education & None & $\begin{array}{l}\text { (1) Incidence } \\
\text { (2) Knowledge }\end{array}$ & $\begin{array}{l}\text { (1) Decreased by } 44 \% \text { (1546 vs } 860 \text { per } 10000 \\
\text { persons) } \\
\text { (2) Improved§ }\end{array}$ \\
\hline Zhao et $a l^{19 *}$ & $\begin{array}{l}\text { Unintentional } \\
\text { injury }\end{array}$ & 2006 & $\begin{array}{l}\text { (1) } 3228 \dagger \\
\text { (2) } 2652 \ddagger\end{array}$ & Children (7-13 years) & $\begin{array}{l}\text { Injury education and campus/ } \\
\text { home check }\end{array}$ & $\begin{array}{l}\text { Non-injury } \\
\text { education }\end{array}$ & (1) Incidence & $\begin{array}{l}\text { (1) Decreased by } 24 \% \text { (863 vs654 per } 10000 \\
\text { persons) } \uparrow\end{array}$ \\
\hline Xing et $a l^{20 *}$ & $\begin{array}{l}\text { Unintentional } \\
\text { injury }\end{array}$ & 2006 & $\begin{array}{l}\text { (1) } 560 \dagger \\
\text { (2) } 495 \ddagger\end{array}$ & Adolescents & Injury education & None & (1) Incidence & $\begin{array}{l}\text { (1) Decreased by } 43 \% \text { ( } 150 \text { vs } 85 \text { per } 1000 \\
\text { persons)§ }\end{array}$ \\
\hline Yang et $a 2^{21 *}$ & $\begin{array}{l}\text { Road traffic } \\
\text { injury }\end{array}$ & 2007 & $\begin{array}{l}\text { (1) } 729 \dagger \\
\text { (2) } 732 \ddagger\end{array}$ & Adolescents & Injury education & None & (1) Knowledge, and behaviour & (1) All Improved§ \\
\hline Yang et $a^{22 *}$ & $\begin{array}{l}\text { Unintentional } \\
\text { injury }\end{array}$ & 2007 & $\begin{array}{l}\text { (1) } 617 \dagger \\
\text { (2) } 583 \ddagger\end{array}$ & Adolescents & Injury education for parents & None & (1) Knowledge and behaviour & (1) Improved§ \\
\hline Liu et $a P^{23 *}$ & $\begin{array}{l}\text { Road traffic } \\
\text { injury }\end{array}$ & 2007 & $\begin{array}{l}\text { (1) } 2346 t \\
\text { (2) } 2076 \ddagger\end{array}$ & Adolescents & Injury education & None & $\begin{array}{l}\text { (1) Incidence } \\
\text { (2) Knowledge and behaviour }\end{array}$ & $\begin{array}{l}\text { (1) Decreased by } 43 \% \text { (148 vs } 84 \text { per } 1000 \\
\text { persons) } \S \\
\text { (2) Improved } \S\end{array}$ \\
\hline Wu et $a l^{24 *}$ & $\begin{array}{l}\text { Road traffic } \\
\text { injury }\end{array}$ & 2008 & $\begin{array}{l}\text { (1) } 265 \dagger \\
\text { (2) } 272 \ddagger\end{array}$ & $\begin{array}{l}\text { Community residents (over } \\
12 \text { years) }\end{array}$ & Injury education & None & $\begin{array}{l}\text { (1) Knowledge, attitude and } \\
\text { practice }\end{array}$ & $\begin{array}{l}\text { (1) All improved for both 1-month and } \\
\text { 12-month follow-up§ }\end{array}$ \\
\hline $\operatorname{Yan}^{25 *}$ & Sport injury & 2008 & $\begin{array}{l}\text { 1) } 956 t \\
\text { 2) } 961 \neq\end{array}$ & Children & $\begin{array}{l}\text { Injury education and campus/ } \\
\text { home check }\end{array}$ & None & $\begin{array}{l}\text { (1) Incidence } \\
\text { (2) Knowledge, attitude, and } \\
\text { behaviour }\end{array}$ & $\begin{array}{l}\text { (1) No statistical differencef } \\
\text { (2) All improvedt }\end{array}$ \\
\hline Sun et $a l^{26 *}$ & $\begin{array}{l}\text { Unintentional } \\
\text { injury }\end{array}$ & 2009 & $\begin{array}{l}\text { (1) } 355 \dagger \\
\text { (2) } 379 \ddagger\end{array}$ & Children (2-6 years) & Injury education & Unclear & $\begin{array}{l}\text { (1) Incidence } \\
\text { (2) Knowledge }\end{array}$ & $\begin{array}{l}\text { (1) Decreased by } 59 \% \text { (5873 vs } 2427 \text { per } \\
10000 \text { persons) } § \\
\text { (2) Improved }\end{array}$ \\
\hline Jiang et $a l^{27 *}$ & $\begin{array}{l}\text { Unintentional } \\
\text { injury }\end{array}$ & 2009 & $\begin{array}{l}\text { (1) } 120 \dagger \\
\text { (2) } 177 \ddagger\end{array}$ & Children (12-14 years) & Injury education & Unclear & $\begin{array}{l}\text { (1) Knowledge, belief, and } \\
\text { behaviour }\end{array}$ & (1) All improved \\
\hline Wang and $\mathrm{Zhu}{ }^{28 *}$ & $\begin{array}{l}\text { Unintentional } \\
\text { injury }\end{array}$ & 2009 & $\begin{array}{l}\text { (1) } 1080 t \\
\text { (2) } 1268 \ddagger\end{array}$ & $\begin{array}{l}\text { Adolescents (mean: } \\
14.5 \text { years) }\end{array}$ & $\begin{array}{l}\text { Peer education for injury } \\
\text { prevention }\end{array}$ & None & $\begin{array}{l}\text { (1) Incidence } \\
\text { (2) Knowledge }\end{array}$ & $\begin{array}{l}\text { (1) Decreased by } 45 \% \text { ( } 519 \text { vs } 286 \text { per } 1000 \\
\text { persons)§ } \\
\text { (2) Improved§ }\end{array}$ \\
\hline Xia et $a l^{29 * *}$ & Fall & 2009 & $\begin{array}{l}\text { (1) } 723 \dagger \\
\text { (2) } 699 \ddagger\end{array}$ & The elderly (over 60 years) & $\begin{array}{l}\text { Injury education and community/ } \\
\text { home check }\end{array}$ & Unclear & $\begin{array}{l}\text { (1) Incidence } \\
\text { (2) Knowledge, attitude and } \\
\text { practice }\end{array}$ & $\begin{array}{l}\text { (1) Decreased by } 60 \% \text { (179 vs } 72 \text { per } 100 \\
\text { persons)ף } \\
\text { (2) All improved } 7\end{array}$ \\
\hline Zheng $^{30 *}$ & $\begin{array}{l}\text { Occupational } \\
\text { injury }\end{array}$ & 2010 & $\begin{array}{l}\text { (1) } 478 \dagger \\
\text { (2) } 562 \ddagger\end{array}$ & $\begin{array}{l}\text { Young adults } \\
\text { (mean:35 years) }\end{array}$ & Injury education & Unclear & (1) Incidence & $\begin{array}{l}\text { (1)Decreased by } 27 \% \text { (1797 vs } 1318 \text { per } 10000 \\
\text { persons) } \uparrow\end{array}$ \\
\hline
\end{tabular}


Table 1 Continued

\begin{tabular}{|c|c|c|c|c|c|c|c|c|}
\hline \multirow[b]{2}{*}{ ID } & \multirow[b]{2}{*}{ Type of injury } & \multirow[b]{2}{*}{ Year } & \multirow[b]{2}{*}{ Sample size } & \multirow[b]{2}{*}{ Study subjects } & \multicolumn{2}{|l|}{ Prevention intervention } & \multirow[b]{2}{*}{ Outcome measures } & \multirow[b]{2}{*}{ Effects of intervention } \\
\hline & & & & & Intervention group & Control group & & \\
\hline Cao and Zhang ${ }^{31 *}$ & All injuries & 2010 & $\begin{array}{l}\text { (1) } 914 \dagger \\
\text { (2) } 823 \ddagger\end{array}$ & Adolescents & $\begin{array}{l}\text { Injury education and campus/ } \\
\text { home check }\end{array}$ & None & $\begin{array}{l}\text { (1) Incidence } \\
\text { (2) Knowledge, attitude and } \\
\text { practice }\end{array}$ & $\begin{array}{l}\text { (1) Decreased } 46 \% \text { ( } 710 \text { vs } 383 \text { per } 1000 \\
\text { persons) § } \\
\text { (2) Improved§ }\end{array}$ \\
\hline Zhang et $a l^{\beta 2 * *}$ & $\begin{array}{l}\text { Road traffic } \\
\text { injury }\end{array}$ & 2010 & $\begin{array}{l}\text { (1) } 776 \dagger \\
\text { (2) } 697 \ddagger\end{array}$ & Adolescents & Injury education & None & $\begin{array}{l}\text { (1) Knowledge, awareness, } \\
\text { and behaviour }\end{array}$ & (1) All improved§ \\
\hline $\mathrm{Ye}^{33 *}$ & $\begin{array}{l}\text { Road traffic } \\
\text { injury }\end{array}$ & 2010 & $\begin{array}{l}\text { (1) } 3202 \dagger \\
\text { (2) } 2433 \ddagger\end{array}$ & Adolescents ( $10-18$ years) & Injury education & None & $\begin{array}{l}\text { (1) Incidence } \\
\text { (2) Knowledge }\end{array}$ & $\begin{array}{l}\text { (1) Decreased by } 35 \% \text { ( } 170 \text { vs } 110 \text { per } 1000 \\
\text { persons)ף } \\
\text { (2) Improved§ }\end{array}$ \\
\hline Zhang ${ }^{34 *}$ & $\begin{array}{l}\text { Unintentional } \\
\text { injury }\end{array}$ & 2010 & $\begin{array}{l}\text { (1) } 122 \dagger \\
\text { (2) } 122 \ddagger\end{array}$ & Infants (17-26 days) & Injury education for parents & $\begin{array}{l}\text { Non-injury } \\
\text { education }\end{array}$ & (1) Incidence & $\begin{array}{l}\text { (1) Decreased by } 76 \% \text { ( } 205 \text { vs } 49 \text { per } 1000 \\
\text { persons) after } 36 \text { months }\end{array}$ \\
\hline Fang et $a^{35 *}$ & All injuries & 2010 & $\begin{array}{l}\text { (1) } 261 \dagger \\
\text { (2) } 271 \neq\end{array}$ & Children & Injury education & None & $\begin{array}{l}\text { (1) Incidence } \\
\text { (2) Knowledge }\end{array}$ & $\begin{array}{l}\text { (1) Decreased by } 24 \% \text { ( } 608 \text { vs } 460 \text { per } 1000 \\
\text { persons)§ } \\
\text { (2) Improved§ }\end{array}$ \\
\hline Fan et $a^{36 *}+\dagger$ & $\begin{array}{l}\text { Unintentional } \\
\text { injury }\end{array}$ & 2006 & Unclear & Adolescents & Injury education & $\begin{array}{l}\text { Non-injury } \\
\text { education }\end{array}$ & (1) Incidence & $\begin{array}{l}\text { (1) Decreased } 42 \% \text { (166 vs } 96 \text { per } 1000 \\
\text { persons)§ }\end{array}$ \\
\hline
\end{tabular}

*Studies were reported in Chinese.

tSample size of intervention group.

†Sample size of control group.
§Effects were examined based on the preintervention and postintervention differences in the intervention group.

IEffects were examined based on differences between intervention group and control group after the intervention.

** Studies were reported in English.

t†Information was not extracted due to the unavailability of full-text article. 
most commonly targeted by RCTs (11 studies), followed by all injuries (6 studies) and road traffic injury (5 studies).

All studies selected education as the intervention. Nineteen studies used education as single intervention, and six studies used education as a part of combined intervention. Education was implemented through lectures, brochures, contests (eg, composition, painting, development of flash animation), panel discussions, or broadcasts. Sixteen studies implemented no intervention in the control group, five studies performed non-injury education intervention as control, and the rest four studies did not specify the intervention of a control group in the publications. The median implementation duration of intervention was 11 months (range: 1-24 months).

Nineteen studies used injury incidence rate as the primary outcome measure; 10 studies reported $24-59 \%$ reductions in injury incidence rate in intervention group and eight studies reported $24-76 \%$ rate difference between intervention group and the control group after the implementation of intervention. Only one study reported no significant difference. The other six studies that used knowledge, attitude and practice/behaviour (KAP) as primary outcome measures reported improvements in KAP.

\section{Quality of included studies}

Using the seven-item checklist recommended by the Cochrane Collaboration, we found that (1) none of the 24 RCTs with full text specified the details of 'allocation concealment', 'blinding' and 'free of early stopping bias'; (2) 23 RCTs did not provide the information of 'adequate sequence generation' and (3) most studies specified the details of 'free of selective outcome reporting' (24 RCTs), 'free of baseline imbalance' (15 RCTs) and 'incomplete outcomes data addressed' (18 RCTs) (figure 2).

\section{DISCUSSION}

Between 2001 and 2010, there were 25 RCTs targeting injury prevention, only accounting for less than $0.5 \%$ of all publications related to injury prevention in China. Strikingly, 24 published RCTs with full text included nothing about the information of 'allocation concealment', 'blinding' and 'free of early stopping bias'. All of 25 RCTs adopted education as single intervention or a part of combined intervention. Eighteen of 19 studies that used injury incidence rate as the primary outcome measures indicated that education can reduce injury incidence rate substantially.

First of all, very few RCTs have been published to support injury prevention decision making during 2001-2010 in China. This scarcity may be due to many reasons, such as high costs and the long time period of conducting RCTs and the lack of governmental support in China. Compared with performing an observational study (cross-section/case-control/cohort study), conducting a RCT often needs more money and longer time. As in the USA 20 years ago, ${ }^{37}$ injury prevention research has rarely received governmental support. Currently, injury prevention has been excluded from the list of health research priorities in China. ${ }^{3}$

Second, even for the limited published 25 RCTs, their conclusions are questionable because the information of 'allocation concealment', 'blinding' and 'free of early stopping bias' was absent in the full-text articles. Without the information, it is hard to determine whether the conclusions were free of bias. This agrees with the empirical findings of qualitative study by Wang, that most published papers on injury prevention in China were of low quality. The absence of the information indicates two possibilities: (1) these requirements were not considered and implemented by the researchers; or (2) these requirements were properly implemented but were not reported. Currently, the editors of most domestic medical journals require the authors to limit the words of a manuscript to within 3000 Chinese words, ${ }^{38}$ potentially restricting the authors to report the implementation details of RCTs.

In order to provide decision makers with high-quality RCTs-based evidence, the following actions are needed:

1. Injury research should be strictly designed and appropriately reported. It will be helpful for domestic injury researchers to abide by the guidelines or checklists developed by international experts when they do their research. The advice that was proposed to improve community intervention research for injury prevention is valuable for domestic injury researchers to carry out RCTs, including 'being guided by a good theoretical model, using multifaceted interventions, involving communities in program planning and implementation, using rigorous process and outcome evaluation, addressing social inequalities in disease and injury risk, incorporating approaches for tailoring interventions to the population level, using appropriate study design, and assessing the durability of intervention and evaluate economic effect'. ${ }^{39}$
Figure 2 Proportions of quality items reported in published randomised controlled trials $(\mathrm{RCT})$ for injury prevention interventions of China, 2001-2010. Note: The study ${ }^{36}$ was excluded from quality evaluation due to the lack full-text article.

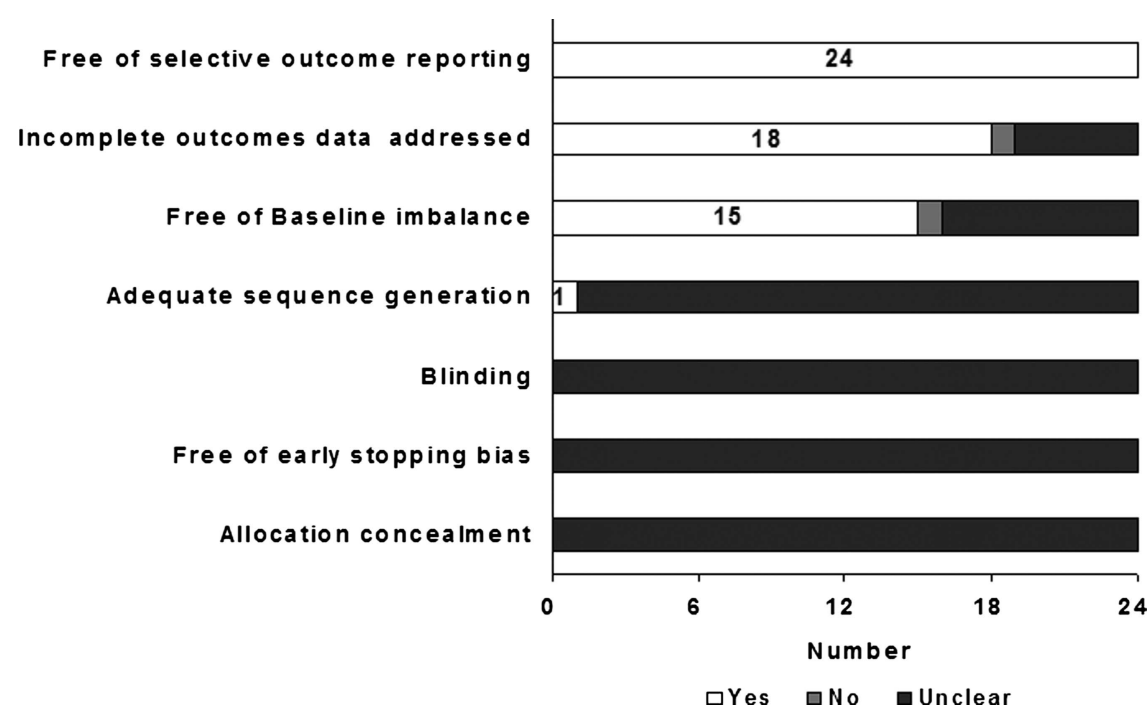


2. Domestic injury researchers should take account other interventions, like environmental approach, engineering method, or legislation in the future, rather than solely concentrating on education. Although $24-76 \%$ reduction in injury rate reflected by the published RCTs was impressive, it was unconvincing because the decrease may be the effects of potential bias that were not clearly addressed in the publications. In particular, such conclusions contradict the findings of strictly designed studies in developed countries that education alone cannot reduce injury, and intervention that provides only information is rarely successful in reducing injury risk behaviours. ${ }^{40}{ }^{41}$ The use of environmental and engineering methods that are aimed to alter the physical environment or modify the design of safety devices may be more effective, but need to be rigorously evaluated in the future. ${ }^{39} 41$

Our study has several limitations. First, we included only the published RCTs indexed in four domestic databases and two international databases within a recent 10 -year period, and reported in Chinese and English. Those unpublished RCTs and those indexed in other academic datasets for injury prevention were excluded. All the same, our findings would not be obviously affected by the selection of search datasets because no extra RCTs were detected when we used search engines like GOOGLE, BAIDU and YAHOO to do the same search. Second, the content analysis and quality evaluation of publications may be biased a little because the evaluation was subjective. ${ }^{42}$ The combination of independent evaluation of two reviewers and group discussion maximally reduced the bias from quality evaluation especially considering that the seven-item checklist for RCTs quality evaluation is easy to be implemented by the reviewers and moderator who have received advanced training in research design and epidemiology, and have many years of experience in epidemiologic studies.

\section{What is already known on this subject}

- Several papers on injury prevention have been published in China.

- Many published papers on injury prevention in China were of low quality.

\section{What this study adds}

- Of 4834 publications on injury prevention, there were only 25 RCTs between 2001 and 2010.

- Nineteen published RCTs used education as a single intervention and six studies used education as a part of combined interventions.

- The value of 25 published full-text RCTs remained undermined due to the exclusion of information of 'allocation concealment', 'blinding' and 'free of early stopping bias'.

- The effectiveness of non-education interventions like law enforcement, environmental and engineering interventions has rarely been evaluated in China.

\section{CONCLUSIONS}

Only 25 published RCTs concentrated on injury prevention between 2001 and 2010 in China. The value of the 25 published RCTs remained undetermined due to the lack of information of quality. High-quality RCTs are needed to support the decision making in injury prevention in China.

Acknowledgements We thank Professor Susan P Baker for her precious comments in regards to this study.

Contributors All authors have contributed to the study design, data analysis and interpretation

Funding This publication was supported by the 2009 New Central Scholar Support Grant of Ministry of Education of China (NCET-10-0782).

Competing interests None.

Provenance and peer review Not commissioned; externally peer reviewed.

\section{REFERENCES}

1 The Ministry of Health of China. The national injury report of China. Beijing: People's Medical Publishing House, 2007.

2 Wang S, Li Y, Chi G, et al. Injury-related fatalities in China: an under-recognised public-health problem. Lancet 2008;372:1765-73.

3 Hu G, Baker TD, Baker SP. Injury control in China: priorities and actions. Lancet 2009;373:214.

4 Wang SY. From data to action: challenging injury control in China. Zhong Hua Yu Fang Yi Xue Za Zhi 2006;40:221-2.

5 Jadad AR. Randomized controlled trials: a user's guide. London, England: BMJ Books, 1998.

6 Peden M, McGee K, Sharma G. The injury chartbook: a graphical overview of the global burden of injuries. Geneva: World Health Organization, 2002.

7 U.S. National Library of Medicine. MEDLINE, PubMed, and PMC (PubMed Central): How are they different? http://www.nlm.nih.gov/pubs/factsheets/dif_med_pub.html (accessed 4 Jul 2013).

8 Wikipedia contributors. Web of Knowledge. Wikipedia, The Free Encyclopedia. 14 June 2013, 09:22 UTC. http://en.wikipedia.org/w/index.php?title=Web_of_ Knowledge\&oldid $=559848618$ (accessed 4 Jul 2013).

$9 \mathrm{Li} Z \mathrm{ZY}$, Guo ZP, Huang HE, et al. The status of injury prevention and control in China. Chin J Prev Control Chronic Non-Commun Dis 2007;15:181-83.

10 Higgins JPT, Green Seds. Cochrane handbook for systematic reviews of interventions version 5.0.0. [updated February 2008]. The Cochrane Collaboration, 2008. http:/l www.cochrane-handbook.org (accessed Jan 2012).

11 Gurusamy KS, Samraj K, Fusai G, et al. Robot assistant for laparoscopic cholecystectomy. Cochrane Database Syst Rev. 2009;(1):CD006578.

12 Dong HM, Wang Y, Yan CK, et al. Evaluation on the effect of intervention measures for injuries in the rural residents of Shijiazhuang city. Chin J Dis Control Prev 2001;5:261-2.

13 Yan CK, Dong HM, Wang Y, et al. Evaluation on the effect of intervention measures for injuries in the urban residents of Shijiazhuang City. Chin I Dis Control Prev 2001;5:244-5.

14 Zhang YK, Lu YH, Ning LF, et al. Effect of prevention on injury of school children in Maoming City. Sci Travel Med 2001;7:4-8.

15 Guo SQ. An intervention study on the effect of health education in child injury-related behavior of Ma-An-Shan city. Hefei: Anhui Medical University, 2004.

16 Zhang Y. Evaluation of injury prevention program based on health education for primary school students. Hefei: Anhui Medical University, 2004.

17 Shen WJ, Xu JX, Zou TH. Health education for injury prevention in house builders of Changning district, Shanghai. In: Wu F, eds. Proceedings of the third International Academic Conference on Environmental and Occupational Medicine; Shanghai: Journal of Environmental and Occupational Medicine, 2004, 239-41.

18 Wang FZ, Chen YQ. Evaluation of unintentional injury prevention in health education for primary and middle school students in the rural. Chin Primary Health Care 2005;19:55

19 Zhao $\mathrm{CH}$, Qiu HS, Qiu HX. Interventions to prevent accidental injuries in children between 7 and 13 years of age. Chin J Contem Pediatr 2006;8:331-3.

20 Xing LL, Yang XJ, Wang W, et al. Comprehensive evaluation of accidental injuries among students in Dongcheng district, Beijing. Chin I Health Educ 2006;22:687-9.

21 Yang J, Guo XH, Xue CJ. Evaluation of traffic road injuries among middle school students in Chaoyang District, Beijing. Chin I Sch Health 2007;28:162-3.

22 Yang DM, Zhang LB, Zhou FM, et al. Effectiveness evaluation of preventing children unintentional injury health education among the parents of primary and middle school students. Chin I Health Educ 2007;23:407-9.

23 Liu XY, Zhang C, Li YQ, et al. Intervention study on road traffic harm of middle school students. Mod Prev Med 2007:34:885-8.

24 Wu W, Zhang YQ, Huang MH, et al. Impact evaluation on traffic harm prevention education among community residents in Nanjing. In: Wu F, eds. Proceedings of the 
Seventh Graduate Academic Conference on Environmental and Occupational Medicine; Shanghai: Journal of Environmental and Occupational Medicine, 2006, 170-4.

25 Yan YJ. A countermeasure study on the prevention of sports injuries among primary school children at Minhang district. Shanghai: Fudan University, 2008.

26 Sun JZ, Chen H, Li Y, et al. The evaluation of the effectiveness of comprehensive intervention for preschool children' accidents. Chin J Pract Pediatr 2009:24:634-6.

27 Jiang BJ, Chen J, Li X, et al. Intervention study of unintentional injury among students of junior high school in Huangpu district, Shanghai. Chin Primary Health Care 2009;23:61-2

28 Wang $X$, Zhu YH. Peer education's effects on preventing accidental injuries in middle school students. J Hyg Res 2009;38:449-51.

29 Xia QH, Jiang Y, Niu CJ, et al. Effectiveness of a community-based multifaceted fall-prevention intervention in active and independent older Chinese adults. Inj Prev 2009;15:248-51.

30 Zheng $\mathrm{L}$. The prevalence, risk factors and evaluation of intervention effects of injuries among construction workers. Wuhan: Huazhong University of Science and Technology, 2010.

31 Cao RX, Zhang R. Pilot intervention of students' injuries in Beijing. Chin J Sch Health 2010;31:1174-7

32 Zhang C, Hong Y, Liu XR, et al. Evaluation of a school-based intervention to reduce traffic-related injuries among adolescents in Beijing. World Health Popul 2010;12:34-42.
33 Ye YR. An intervention study on bicycle injuries of middle school students in rural China. Shantou: Shantou University, 2010.

34 Zhang YJ. Effect of early safety education intervention on infant unintentional injury prevention. Nurs Rehabil J 2010;9:697-8.

35 Fang YW, Zhu HL, Duan JW, et al. Evaluation of the project to create health promotion kindergarten in Zhoushan. Chin J Sch Health 2010;31:1245-6.

36 Fan YP, Sun YH, Yu XD, et al. Study of unintentional injury prevention based on health education for Students in middle and primary Schools. In: Zhuang $\mathrm{H}$, eds. Proceedings of the Second Annual Academic Conference of China Preventive Medicine Association and Global Chinese Public Health Association; 2006, 422

37 Sleet DA, Baldwin G, Marr A, et al. History of injury and violence as public health problems and emergence of the National Center for Injury Prevention and Control at CDC. J Safety Res 2012;43:233-47.

38 Zhu D, Huang W, Li $X$, et al. Preliminary analysis of randomized controlled trials related to nursing. J Pract Nurs 2003;19:60-1.

39 Doll LS, Bonzo SE, Mercy JA, et al. Handbook of injury and violence prevention. New York: Springer Science + Business Media, LLC, 2007.

40 Duperrex 0 , Roberts I, Bunn F. Safety education of pedestrians for injury prevention. Cochrane Database of Syst Rev 2002;(2):CD001531.

41 Rautiainen RH, Lehtola MM, Day LM, et al. Interventions for preventing injuries in the agricultural industry. Cochrane Database of Syst Rev, 2008;(2):CD006398.

42 Yavchitz A, Boutron I, Bafeta A, et al. Misrepresentation of randomized controlled trials in press releases and news coverage: a cohort study. PLoS Med 2012;9:1-11.

\section{ACC's new approach to injury prevention}

The Accident Compensation Commission (ACC) in NZ is updating its approach to injury prevention. The new approach based on various criteria led to the choice of seven priority areas: falls, road, workplace, treatment, sport and recreational, lifting, carrying and strain injuries, and intentional harm. (Noted by IBP)

\section{Opposition to limits on cellphone use}

An attempt in Louisiana to prohibit hand-held cellphone use by motorists faced widespread resistance in the legislature in spite of support by the insurance industry. Opponents said the measure arbitrarily picks on one type of distracted driving and criticised it as a 'nanny state' bill. Even as a secondary offence the opposition was unyielding. (Noted by IBP)

\section{Rear cameras better than parking sensors}

Rear cameras work better than parking sensors at preventing drivers from running over children while backing up. About 292 people, especially children and the elderly, are killed and 18000 injured each year by drivers who back into them, typically in driveways or parking lots. Larger vehicles pose greater risks because drivers cannot easily see people near the ground. Sport-utility vehicles and pickup trucks typically have the largest blind zones. (Noted by IBP) 